\title{
The influence of trematodes on the macroalgae consumption by the common periwinkle Littorina littorea
}

\author{
KARIN T. CLAUSEN, MARTIN H. LARSEN, NINA K. IVERSEN AND KIM N. MOURITSEN \\ Department of Biological Sciences, University of Aarhus, Finlandsgade 14, DK-8200 Aarhus N, Denmark
}

\begin{abstract}
Trematodes are ubiquitous elements of coastal ecosystems that commonly modify the phenotype of their invertebrate hosts, often with ramifications to higher levels of ecological organization. In this context, trematode infections have been suggested to reduce the consumption of the herbivorous gastropod Littorina littorea (L.) (Mollusca: Gastropoda), in turn affecting the composition of the macroalgal community on which the snail grazes. Here, we examine the effect of two species of trematodes, Renicola roscovita and Himasthla elongata, on L. littorea's consumption in two outdoor microcosm experiments offering the snails two different ephemeral green algae species as a food source. Our results show that, irrespective of the species of parasite and food source, infection decreases consumption: uninfected snails consumed up to 65\% more macroalgal biomass than infected snails. Aside from infection status, gender and size also influenced the snails' consumption rate significantly. The differing histopathological impacts of the two species of trematodes on the hosts' gonad-digestive gland complex (in which the parasites reside), suggests that parasitic castration is a likely mechanism for the reduced energy demand of infected periwinkles. Together with existing evidence, our investigation suggests that trematodes in general depress the grazing activity of $\mathrm{L}$. littorea, and that the resulting community regulation occurs throughout the snails' distributional range.
\end{abstract}

Keywords: consumption, Enteromorpha intestinalis, Himasthla elongata, macroalgae community, parasites, Renicola roscovita, Ulva lactuca

Submitted 11 February 2008; accepted 10 March 2008; first published online 29 July 2008

\section{INTRDDUCTIDN}

It is well known that parasites can interfere with essential aspects of the life of their host, such as growth rate, behaviour, reproduction and survival (e.g. Combes, 2001; Mouritsen \& Poulin, 2002; Poulin, 2007). If the host is abundant or otherwise ecologically influential, such host-parasite interactions may well impact higher levels of organization, and parasitism is increasingly recognized as an important factor structuring natural communities (Pennings \& Callaway, 1996; Hudson \& Greenman, 1998; Combes, 2001; Mouritsen \& Poulin, 2002, 2005; Thomas et al., 2005; Begon et al., 2006; Poulin \& Mouritsen, 2006; Wood et al., 2007). In this perspective, and considering that ecological understanding to a large extent rests on knowledge of factors determining the flow of energy through ecosystems, surprisingly little is known about the effect of parasitism on host consumption rates, particularly of marine host organisms.

The periwinkle Littorina littorea (L.) is an important grazer in coastal habitats on both sides of the North Atlantic (e.g. Lein, 1980; Bertness, 1999). It prefers rapidly growing, ephemeral green algae lacking structural defences over mechanically and chemically defended perennial species, such as brown and red algae. Hence, L. littorea may significantly alter the community composition of primary producers in

Corresponding author:

K.N. Mouritsen

Email: kim.mouritsen@biology.au.dk a density-dependent manner, and experiments by Lubchenco (1978) have clearly emphasized this structuring role in tidal pools along New England's coast. Due to interspecific competition among algae, the tidal pools are dominated by rapidly colonizing, ephemeral green algae when $L$. littorea is rare or absent, while perennial algae dominate in pools with high periwinkle densities.

The vast majority of gastropod parasites are trematodes (Lauckner, 1980). Littorina littorea serves as first intermediate host to a range of trematode species that also include benthic invertebrates, fish and shorebirds in their often complex lifecycle (Werding, 1969; Curtis, 2002). In northern European waters, the common periwinkle is frequently host to at least six trematode species: Cercaria lebouri, Cryptocotyle lingua, Himasthla elongata, Podocotyle atomon, Renicola roscovita and Microphallus pygmaeus (Werding, 1969; Lauckner, 1980; Curtis 2002). The parasites infect the gonad-digestive gland complex of the snail, where they reproduce asexually, eventually resulting in castration and possibly also reduced digestive capacity of the host (Werding, 1969; Lauckner, 1987; Huxham et al., 1993; Mouritsen et al., 1999; Wood et al., 2007).

Recently, Wood et al. (2007) demonstrated that one of these trematode species, C. lingua, caused infected L. littorea-introduced to the north-west Atlantic coast in the mid-19th Century-to consume fewer green algae (Ulva lactuca) than uninfected snails, and further showed that this could ultimately affect the composition of the macroalgal community. Wood et al. (2007) suggested that infected 
snails consumed less than uninfected snails due to parasite-inflicted damage to the digestive gland and/or reduced energy demand, e.g. as a consequence of parasitic castration or parasite-induced growth retardation.

In the east Atlantic distributional range, L. littorea is host to a larger diversity of trematode species than are snails along the North American coast, where C. lingua dominates the trematode fauna (Curtis, 2002; Byers et al., 2008; Blakeslee $\&$ Byers, 2008). In Danish and adjacent waters $R$. roscovita is one of the most widespread species, reaching local prevalences exceeding 70\% (Werding, 1969; Mouritsen et al., 1999; personal observation). As opposed to e.g. C. lingua, which ultimately infests the entire gonad-digestive gland complex of the snail, a Renicola-infection appears as a localized orange abscess mass of larval parasites, leaving larger parts of the gonads and digestive gland unaffected (Werding, 1969; personal observation). This histopathological difference between the two trematode species could result in divergent effects on host consumption and, in turn, divergent community impacts stemming from hostparasite interaction.

The aims of our study were: (1) to investigate the impact of trematode species other than C. lingua on consumption by $L$. littorea, in order to determine whether the effect is speciesspecific or general; (2) to provide further insight into the mechanism by which the parasites influence host consumption by focusing on Renicola-infections, which have limited mechanical impact on host tissues; and (3) to determine whether the effect of trematodes on host consumption is independent of habitat/food source by offering the periwinkles macroalgae species characteristic for both hard- and softbottom habitats.

\section{MATERIALS AND METHDDS}

In summer 2007, two outdoor microcosm experiments were performed at Rønbjerg Marine Biological Station, Limfjorden, Denmark ( $\left.56^{\circ} 53^{\prime} 29^{\prime \prime} \mathrm{N} 9^{\circ} 9^{\prime} 52^{\prime \prime} \mathrm{E}\right)$, examining the effect of infection status (uninfected or infected by larval trematodes) of periwinkles L. littorea on the consumption of the macroalgae Enteromorpha intestinalis (experiment $1 ; 25$ June to 3 July) and Ulva lactuca (experiment 2; 2 to 7 of July). Enteromorpha intestinalis is an important food source for periwinkles in hard-bottom habitats, whereas $U$. lactuca dominates on the soft-bottom.

\section{Experiment 1}

A plastic cup ( $500 \mathrm{ml}, 12 \mathrm{~cm}$ high) served as the experimental unit in which green algae and the herbivorous snails were established. Two hundred and forty-five such cups were arranged in an outdoor container (200/200/55 cm length/ width/height) provided with running seawater (17-21\%o). The water depth was adjusted to $30 \mathrm{~cm}$, ensuring that all cups were submerged. The mean water temperature during the experiment was $19.4^{\circ} \mathrm{C}$ (range: 17.1-20.7), measured every 30 minutes by a submerged temperature-logger.

Enteromorpha intestinalis collected at a nearby locality was rinsed and prepared for each cup by a standardized draining procedure, in which a small amount of algae was rotated manually 30 times in a sling mesh ( $\sim$ three rotations per second). The drained wet weight (ww) was then determined to nearest $0.01 \mathrm{~g}$ and a known amount (1.89-2.19 g) was added to each of the 245 cups.

Adult periwinkles $(>8 \mathrm{~mm}$ in shell height) were collected on a stone jetty outside of Rønbjerg Harbour. To optimize the number of trematode infected periwinkles in the experiment, we generally selected for snails with coloured feet, as infected $L$. littorea often possess an orange foot while uninfected individuals generally have a pale foot (Willey \& Gross, 1957). Subsequently, we also selected for larger sized individuals since large (older) snails are more likely to be infected than small (younger) ones (James, 1968; Robson \& Williams, 1970; Lauckner, 1980; Hughes \& Answer, 1982). The snails collected, initially of unknown infection status, gender and shell height, were placed individually in 225 of the 245 cups. The remaining 20 cups without periwinkles served as controls to determine the growth of macroalgae without grazing. All cups were individually covered with mesh ( $2 \mathrm{~mm}$ mesh size) and secured with a rubber band to ensure that E. intestinalis and the snail remained in the cup during the experiment. A small stone was placed in each cup as a stabilizing element and to keep the macroalgae fixed at the bottom.

The experiment was terminated after eight days, which ensured that none of the snails had depleted their offered food sources. Remaining E. intestinalis was drained according to the procedure described above and the wet weight was determined. The shell height (apex to aperture) of periwinkles was measured to the nearest $0.1 \mathrm{~mm}$ using a digital slide caliper, and the snails were then dissected under a stereo microscope to determine sex and the presence of primary infections by larval trematodes in the gonad-digestive gland complex.

\section{Experiment 2}

The second experiment used U. lactuca instead of E. intestinalis as a food source, and followed the same protocol as above with few exceptions. Two hundred and fifty-five cups $(250 \mathrm{ml}$, $8.5 \mathrm{~cm}$ high) were established in three similar sized outdoor containers (100/100/45 cm length/weight/height) supplied with running seawater $(17-23 \%)$. Eighty-five cups containing between 0.90 and $1.10 \mathrm{~g} \mathrm{U}$. lactuca (ww) were submerged in each container. The mean water temperature during the experiment was $17.5^{\circ} \mathrm{C}$ (range: $15.1-22.2$ ). Twenty of the 255 cups served as controls without grazers, and these were distributed as evenly as possible among the three experimental containers.

The microcosms were, in both experiments, submerged in a common water body, and thus, cannot be considered entirely independent. The experimental design also allowed the escape of small pieces of algae through the $2 \mathrm{~mm}$ mesh fastened on the top of each cup. We find, however, that these experimental conditions did not compromise our analysis. First, we cannot envisage any realistic factor-communicated between microcosms through the water body-that might have influenced the qualitative outcome of the investigation. On the contrary, the common water body provided the experiments with greater realism, in addition to ensuring welloxygenated microcosms through a constant water exchange. Secondly, potential escape of small pieces of algae through the mesh was a condition common to all experimental units, and therefore could not have affected the qualitative nature of the results. 


\section{Data analyses}

The statistical analyses were performed in SPSS 14.0 (Statistical Package for the Social Sciences). We tested for the assumption of homogeneity of variance and normal distribution prior to main parametric tests. If violated (as in experiment 1), data were ln-transformed to meet these assumptions. We used a full factorial ANOVA to evaluate the effect of infection by $R$. roscovita (the most frequent species of trematode) and potentially confounding variables (shell height and gender) on consumption. As a supplement, parametric or non-parametric paired tests were applied on restricted data sets (e.g. regarding the rare Himasthlainfections). In those cases, snails meeting the criteria for pairing were selected as encountered in a randomized data base. Variation in association with recorded mean values is given as standard error ( \pm 1 SE) throughout. Two snails were lost from experiment 2 during the post-experimental processing and the shell height or gender was not determined for five further individuals. This reduced the effective sample size in the ANOVA accordingly.

\section{RESULTS}

Two different trematode species, $R$. roscovita and $H$. elongata, were encountered in the experiments. The prevalence of $R$. roscovita was 17.0 and $16.4 \%$ in experiments 1 and 2, respectively. In comparison, $H$. elongata infections were rare, showing a prevalence of 2.2 and $0.9 \%$, respectively. A single snail in experiment 1 was infected by both species of trematode, and this individual was excluded in the following analysis.

\section{Renicola roscovita (experiment 1)}

Female periwinkles dominated the sample (63.0\%; goodness-of-fit test, $\left.\chi_{1}^{2}=14.84, P<0.0005\right)$. Overall mean shell-height was $19.5 \pm 0.08 \mathrm{~mm}$, and similar between infected and uninfected snails (Student's $t$-test, $t_{217}=0.02$, $P=0.984)$.

The snails' consumption was significantly affected by both the status of infection, gender and shell-height (Table 1). Uninfected snails consumed on average $18.1 \%$ more algal mass (in terms of wet weight disappeared) than Renicola-infected conspecifics, and females generally

Table 1. Summary statistics of the full factorial ANOVA including the status of infection (uninfected or infected by Renicola roscovita) and sex (male or female) as fixed factors, and shell-height as co-variable, on the consumption of the green alga Enteromorpha intestinalis by periwinkles Littorina littorea as dependent variable (ln-transformed data). A preceding full model demonstrated lack of significant two-way interaction between status of infection and $\operatorname{sex}\left(F_{1,214}=1.34, P=0.25\right)$, and associated sum of squares and df are included in the error variation in the present analysis. Partial $\eta^{2}$ for the reduced model equals 0.788 .

\begin{tabular}{lrlrl}
\hline Source of variation & df & Mean squares & \multicolumn{1}{l}{$\boldsymbol{F}$} & $\boldsymbol{P}$ \\
\hline Status of infection & 1 & 0.595 & 7.66 & 0.006 \\
Sex & 1 & 0.376 & 4.84 & 0.029 \\
Shell height & 1 & 0.961 & 12.38 & 0.001 \\
Error & 215 & 0.078 & & \\
\hline
\end{tabular}

consumed 9.4\% more than males (Figure 1). Furthermore, the consumption was generally positively related to snail size, although the residual variation was large $\left(r_{217}^{2}=0.032\right)$. This relationship was particularly evident in the group of infected snails $\left(\mathrm{r}_{36}^{2}=0.239\right)$. In the control treatment with no snails, the biomass of $E$. intestinalis increased by $0.70 \pm 0.10 \mathrm{~g}$, corresponding to an increase in mean biomass of $34 \%$ during the course of the experiment.

\section{Renicola roscovita (experiment 2)}

Although male periwinkles dominated (56.3\%), the sex-ratio was not statistically different from even (goodness-of-fit test, $\left.\chi_{1}^{2}=3.672, P<0.055\right)$. Infected snails were on average slightly larger $(20.8 \pm 0.35 \mathrm{~mm})$ than uninfected $(20.0 \pm 0.11 \mathrm{~mm}$; Student's $t$-test, $\left.t_{45.14}=2.107, P=0.041\right)$. The biomass of $U$. lactuca increased in the control treatment by $0.35 \pm 0.07 \mathrm{~g}$, corresponding to an increase in mean biomass of $35 \%$ during the course of the experiment.

The snails' consumption of U. lactuca followed the same pattern as in the preceding experiment: uninfected consumed more $(65.1 \%$ on average) than infected snails and females consumed more $(45.8 \%$ on average) than males (Figure 2). Statistically, however, the effect of infection status was (as opposed to sex) not significant $(P=0.081)$ (Table 2). Moreover, the significant positive relationship demonstrated between consumption and snail size in the Enteromorphaexperiment could not be reproduced using $U$. lactuca as food source (Table 2). Focusing on infected and uninfected snails separately, a positive relationship was in fact evident in the latter group $\left(\mathrm{r}_{186}^{2}=0.037, P=0.008\right)$ but not in the former $\left(r_{36}^{2}=0.072, P=0.103\right)$. These inconsistencies between experiments and the relatively low overall proportion of variation explained by the statistical model in the Ulva-experiment as opposed to the Enteromorpha-experiment (see text to Table 1 and 2), prompted us to test the isolated effect of infection status on $U$. lactuca consumption also in a paired $t$-test (paired according to shell-height $( \pm 0.2 \mathrm{~mm})$ and sex). Although this procedure reduced the sample size considerably, the analysis demonstrated a statistically significant lower consumption of $U$. lactuca by infected than uninfected snails $\left(t_{35}=2.74, P=0.01\right)$.

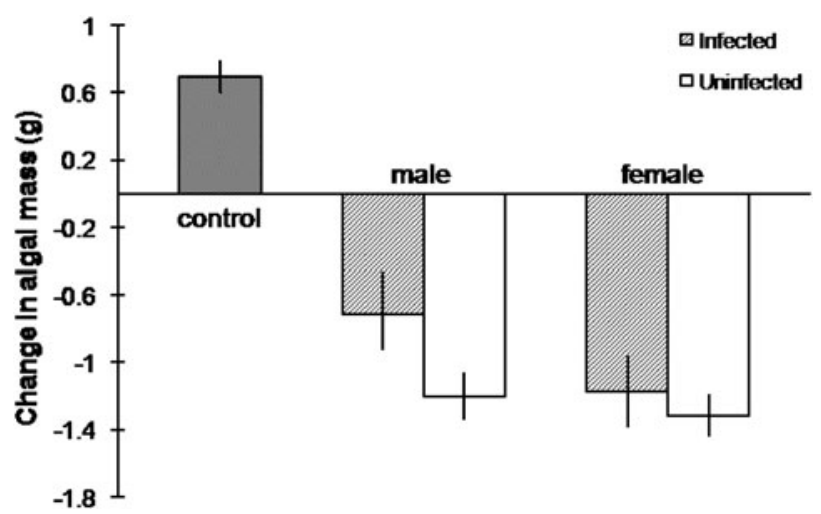

Fig. 1. Change in the mass (g wet weight) of Enteromorpha intestinalis over the course of an 8-day outdoor microcosm experiment. Control, $\mathrm{N}=20$; uninfected males, $\mathrm{N}=73$; infected males, $\mathrm{N}=8$; uninfected females, $\mathrm{N}=108$; infected females, $\mathrm{N}=30$. Values are means $\pm 1 \mathrm{SE}$. 


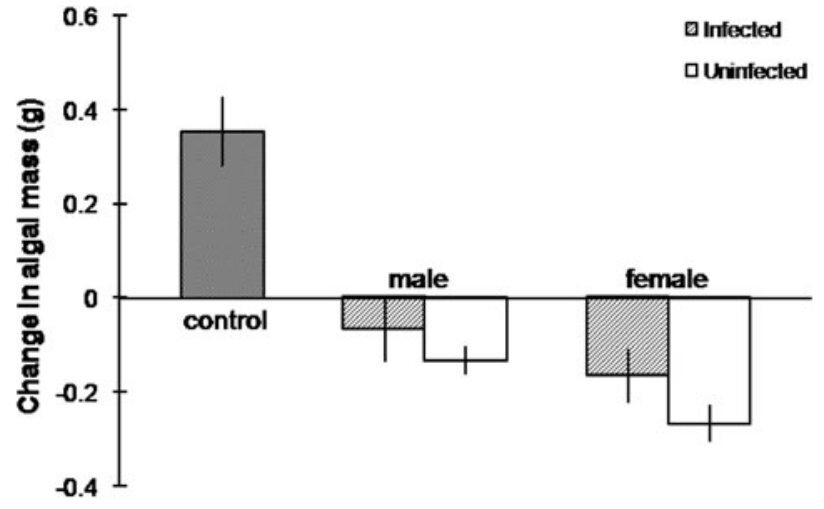

Fig. 2. Change in the mass (g wet weight) of Ulva lactuca over the course of a 5-day outdoor microcosm experiment. Control, $\mathrm{N}=20$; uninfected males, $\mathrm{N}=111$; infected males, $\mathrm{N}=17$; uninfected females, $\mathrm{N}=76$; infected females, $\mathrm{N}=21$. Values are means $\pm 1 \mathrm{SE}$.

\section{Himasthla elongata (experiments 1 and 2)}

Although $H$. elongata infections were rare $(\mathrm{N}=5$ and $\mathrm{N}=2$ in experiments 1 and 2, respectively), the qualitative effect of this trematode species on the periwinkles consumption was analysed using a Wilcoxon signed-rank test for both experiments considered together. Hence, each of the seven infected snails was paired with uninfected counterparts according to experiment (1 and 2$)$, shell height $( \pm 0.1 \mathrm{~mm})$ and sex. In line with the data on Renicola-infections, Himasthla significantly reduced the consumption rate of its host $(Z=2.028$, $P=0.043)$. The daily removal of algal mass was on average $0.11 \pm 0.03 \mathrm{~g}$ for infected and $0.17 \pm 0.02 \mathrm{~g}$ for uninfected snails, corresponding to a $50 \%$ higher consumption rate in the latter group of periwinkles.

\section{DISCUSSIDN}

The present results demonstrate that infections by the trematode $R$. roscovita and $H$. elongata have a negative effect on the consumption rate of European common periwinkles, L. littorea, when feeding on both E. intestinalis (mostly inhabiting stony shores) and U. lactuca (mostly inhabiting soft-bottom habitats). Wood et al. (2007) reached a similar conclusion in periwinkles recently introduced to New England and infected by a different species of trematode, C. lingua. Together, our results and those of Wood et al.

Table 2. Summary statistics of the full factorial ANOVA including the status of infection (uninfected or infected by Renicola roscovita) and sex (male or female) as fixed factors, and shell-height as co-variable, on the consumption of the green alga Ulva lactuca by periwinkles Littorina littorea as dependent variable. A preceding full model demonstrated lack of significant two-way interaction between status of infection and sex $\left(F_{1,220}=0.19, P=0.66\right)$, and associated sum of squares and df are included in the error variation in the present analysis. Partial $\eta^{2}$ for the reduced model equals 0.252 .

\begin{tabular}{lrlll}
\hline Source of variation & df & Mean squares & $\boldsymbol{F}$ & $\boldsymbol{P}$ \\
\hline Status of infection & 1 & 0.329 & 2.07 & 0.081 \\
Sex & 1 & 0.717 & 6.69 & 0.010 \\
Shell height & 1 & 0.194 & 1.81 & 0.180 \\
Error & 221 & 0.107 & & \\
\hline
\end{tabular}

(2007) suggest that trematode infections in general depress the consumption rate by L. littorea throughout the snail's distributional range and regardless of the identity of its food source.

Wood et al. (2007) discussed possible mechanisms and concluded that the lower consumption rates of infected snails were a consequence of either (1) damage to the digestive gland causing reduced capacity of the digestive system and/or (2) reduced energy demands following from the parasite-induced castration and reduced growth. However, the present evidence that Renicola-infections also reduce the consumption of the host provides a unique opportunity to narrow down the mechanisms involved. As opposed to other species of trematodes that eventually infest the entire gonad-digestive gland complex of the host through asexual reproduction, Renicola-infections occur as restricted, isolated abscesses, leaving large parts of the digestive system unaffected (Werding, 1969; personal observation; Figure 3). Hence, the lower consumption rate of infected snails may not follow from destruction of the alimentary system as such, but may rather be a result of reduced energy demands due to parasitic castration and growth retardation. The latter has previously been shown in the studied population of periwinkles (Mouritsen et al., 1999). However, the destruction done by the parasites, regardless of magnitude, will only serve to reduce host consumption further.

Littorina littorea is a potent regulator of chlorophyceae and thus often controls the overall community structure of macroalgae in the coastal zone (Lubchenco, 1978; Lein, 1980; Bertness, 1999; Wood et al., 2007). To the extent that trematode infections reduce consumption by L. littorea, these parasites may indirectly affect the composition of the macroalgal community. Wood et al. (2007) confirmed this prediction in a field experiment by showing a relatively greater abundance of ephemeral macroalgae in treatments with a high proportion of Cryptocotyle-infected snails relative to treatments with a high proportion of uninfected snails. The present investigation suggests that this community structuring process occurs throughout the distributional range of periwinkles and is independent of the species of trematodes involved. However, whether and to what extent trematodes indirectly structure the community of macroalgae in situ depends on several factors other than parasites. First, the consumption rate of periwinkles was, in the present study, found to differ

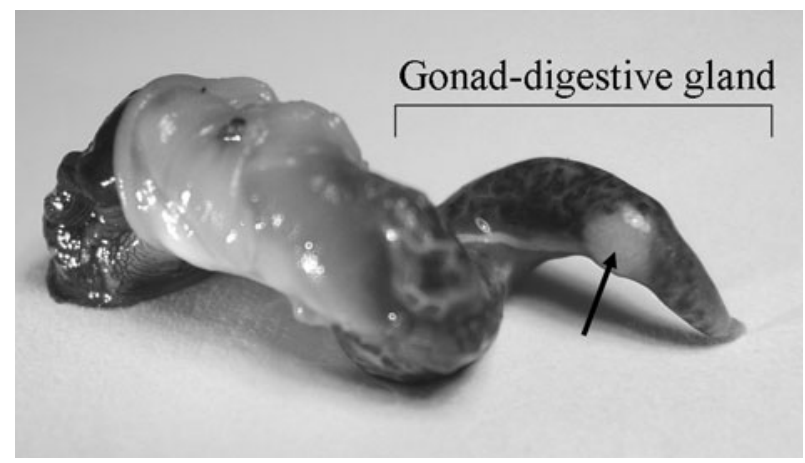

Fig. 3. Soft parts of a periwinkle Littorina littorea infected by the trematode Renicola roscovita. Note that the infection (asexually reproduced larval trematodes) is limited to a well-defined abscess (arrow) situated in upper part of the gonad-digestive gland complex. The abscess will appear creamy-white and orange in immature and mature infections, respectively. 
between males and females and was also affected by snail size, partly in agreement with the observations by Wood et al. (2007). Hence, whether or not the algae community will differ between sites where snails are respectively uninfected and heavily infected will depend on the size-frequency distribution and sex-ratio in the two populations of periwinkles. Second, where snail abundance is regulated by the habitat's carrying capacity (equilibrium), a predominance of trematodes may not favour the occurrence of ephemeral algae. Instead it might allow a greater density of periwinkles or other species of herbivores through immigration or increased settling of recruits (compensation by population increase). Third, the composition of the macroalgal community may also remain unchanged in a partly infected population of L. littorea if uninfected snails (or other herbivores) can increase the rate of consumption as a function of increasing abundance of primary producers (compensation by increased consumption). Fourth, the exact quality of the structuring effect of trematodes (i.e. whether algal diversity increases or decreases) will, at least in more or less isolated subpopulations of snails (e.g. tidal pools), intrinsically depend on the initial abundance of hosts (see Lubchenco, 1978).

Periwinkles are indeed significant regulators of nearcoastal algae communities, and trematodes clearly posses the potential to mitigate this structuring role. However, the future challenge will be to unravel the importance of the above mentioned contributing variables and processes in order to determine whether the presence of these parasites ultimately change the community of primary producers.

\section{ACKNDWLEDGEMENTS}

We wish to thank James E. Byers, Chelsea L. Wood, Jens T. Christensen and anonymous referees for constructive comments on an earlier draft. The study was supported financially by a grant from the Carlsberg Foundation (to K.N.M.).

\section{REFERENCES}

Begon M., Townsend C.R. and Harper J.L. (2006) Ecology. Oxford: Blackwell Publishing.

Bertness M.D. (1999) The ecology of Atlantic shorelines. Sunderland, MA: Sinauer Associates.

Blakeslee A.M.H. and Byers J.E. (2008) Using parasites to inform ecological history: comparisons among three congeneric marine snails in North America and Europe. Ecology 89, 1068-1070.

Byers J.E., Blakeslee A.M.H., Linder E., Cooper A.B. and Maguire T.J. (2008) Controls of spatial variation in the prevalence of trematode parasites infecting a marine snail. Ecology 89, 439-451.

Combes C. (2001) Parasitism: the ecology and evolution of intimate interactions: Chicago: University of Chicago Press.

Curtis L.A. (2002) Ecology of larval trematodes in three marine gastropods. Parasitology 124, 43-56.

Hudson P. and Greenman J. (1998) Competition mediated by parasites: biological and theoretical progress. Trends in Ecology and Evolution 13, $387-390$.

Hughes R.N. and Answer P. (1982) Growth, spawning and trematode infection of Littorina littorea from an exposed shore in North Wales. Journal of Molluscan Studies 48, 321-330.
Huxham M., Raffaelli D. and Pike A. (1993) The influence of Cryptocotyle lingua (Digenea: Platyhelminthes) infections on the survival and fecundity of Littorina littorea (Gastropoda: Prosobranchia); an ecological approach. Journal of Experimental Marine Biology and Ecology 168, $223-238$.

James B.L. (1968) The distribution and keys of species in the family Littorinidae and their digenean parasites, in the region of Dale, Pembrokeshire. Field Studies 2, 615-650.

Lauckner G. (1980) Diseases of Mollusca: Gastropoda. In Kinne O. (ed.) Diseases of marine animals, Volume 1. Hamburg: Biologische Anstalt Helgoland, pp. 311-424.

Lauckner G. (1987) Ecological effects of larval trematoda infestation on littoral marine invertebrate populations. International Journal for Parasitology 17, 391-398.

Lein T.E. (1980) The effects of Littorina littorea L. (Gastropoda) grazing on littoral green algae in the inner Oslofjord, Norway. Sarsia, 65, 87-92.

Lubchenco J. (1978) Plant species diversity in a marine intertidal community: importance of herbivore food preference and algal competitive abilities. American Naturalist 112, 23-39.

Mouritsen K.N., Gorbushin A. and Jensen K.T. (1999) Influence of trematode infections on in situ growth rates of Littorina littorea. Journal of the Marine Biological Association of the United Kingdom 79, 425-430.

Mouritsen K.N. and Poulin R. (2002) Parasitism, community structure and biodiversity in intertidal ecosystems. Parasitology $124, \mathrm{~S}_{101}-\mathrm{S}_{117}$.

Mouritsen K.N. and Poulin R. (2005) Parasitism can influence the intertidal zonation of non-host organisms. Marine Biology 148, 1-11.

Pennings S.C. and Callaway R.M. (1996) Impact of a parasitic plant on the structure and dynamics of salt marsh vegetation. Ecology 77, $1410-1419$.

Poulin R. (2007) Evolutionary ecology of parasites. Princeton: Princeton University Press.

Poulin R. and Mouritsen K.N. (2006) Climate change, parasitism and the structure of intertidal ecosystems. Journal of Helminthology 80, $183-191$.

Robson E.M. and Williams I.C. (1970) Relationships of some species of digenea with the marine prosobranch Littorina littorea (L.). I. The occurrence of larval digenea in L. littorea on the north Yourkshire coast. Journal of Helminthology 44, 153-168.

Thomas F., Bonsall M.B. and Dobson A.P. (2005) Parasitism, biodiversity, and conservation. In Thomas F., Renaud F. and Guegan J-F. (eds.) Parasitism and ecosystems. Oxford: Oxford University Press, pp. 124-139.

Werding B. (1969) Morphologie, entwicklung und ökologie digener trematoden-larven der strandschnecke Littorina littorea. Marine Biology 3, 306-333.

Willey C.H. and Gross P.R. (1957) Pigmentation in the foot of Littorina littorea as a means of recognition of infection with trematode larvae. Journal of Parasitology 43, 324-327.

and

Wood C.L., Byers J.E., Cottingham K.L., Altman I., Donahue M.J. and Blakeslee A.M.H. (2007) Parasites alter community structure. Proceedings of the National Academy of Sciences of the United States of America 104, 9335-9339.

\section{Correspondence should be addressed to:}

Kim N. Mouritsen

Department of Biological Sciences

Marine Ecology, University of Aarhus

Finlandsgade 14, DK-8200 Aarhus N, Denmark

email: kim.mouritsen@biology.au.dk 